\title{
Prevalence of Viral Disease among Diabetic Subjects Attending BIRDEM General Hospital OPD, Dhaka, Bangladesh
}

\author{
Moniruzzaman Khan $\mathbf{M}^{1 *}$, Nazrul Islam $\mathbf{M}^{2}$, Khanum $\mathbf{H}^{3}$ and Maria Ferdaush $\mathrm{U}^{4}$ \\ ${ }^{1}$ Registrar, Department of Dermatology, BIRDEM General Hospital, Bangladesh \\ ${ }^{2}$ Professor, Department of Dermatology, BIRDEM General Hospital, Bangladesh \\ ${ }^{3}$ Professor, Department of Zoology, Dhaka University, Bangladesh \\ ${ }^{4}$ MSc Student, Department of Zoology, Dhaka University, Bangladesh
}

\section{Research Article \\ Volume 5 Issue 4}

Received Date: December 10, 2020

Published Date: December 30, 2020

DOI: $10.23880 /$ cdoaj-16000226

*Corresponding author: Mohammad Moniruzzaman Khan, Registrar, Department of

Dermatology, BIRDEM General Hospital, Dhaka, Bangladesh, Tel: 01736850302; Email: aminuli4343@gmail.com

\section{Abstract}

Background: Skin and venereal disease is one of the major public health problem of the mankind. People within sanitary, overcrowding, poor housing, lack of knowledge regarding disease transmission are suffers more with skin disease. Especially diabetes, are more prone to be attacked by viral diseases due to poor immune status.

Objective: The present study was carried out with the objective to find out prevalence of different viral disease among diabetic subjects and to provide a descriptive profile of prevalence of herpes zoster, Molluscum contagiosum, genital herpes, chicken pox and Pityriasis rosa among the diabetic patients.

Methodology: The study was carried out in skin and VD (Outpatient Department) of BIRDEM General Hospital, Dhaka, Bangladesh enrolling 173 diabetic patients by interviewing with the help of a questionnaire. Diseases were diagnosed by consultant doctor of the department on basis of proper history taking and clinical presentation.

Results: It was observed that the major proportion of the patients (43.35\%) were in the age group between 25-34 years and the group $65+(0.8 \%)$. Majority (64.16\%) of the patients was male. The remaining (35.84\%) were female. Out of 173 patients, $55.49 \%$ lower, $25.43 \%$ middle, $12.14 \%$ upper middle and $6.94 \%$ were belonging to higher socio-economic status (SES). Regarding socio-economic status it was observed that majority of the respondents $(61.33 \%)$ and $(60.87 \%)$ were from lower status group having herpes zoster and genital herpes. In case of pityriasis rosea and Molluscum contagiosum were more prevalent in lower socio-economic status (50\% and 52\%). Highest percentage of the respondents acquired the disease from the slum areas $(26.01 \%)$ and then infected lilen $(20.23 \%)$ and $14.45 \%$ and $13.29 \%$ patients were suffer from camps and jail Also $8.67 \%$ and $5.78 \%$ patients were suffering from school source and playing partners and $11.56 \%$ were suffering husband and wife source. Majority of the skin diseases affected chest (27.74\%) and limbs (16.18\%). Regarding seasonal variation highest percentage of diseases occur in spring season (47.30\%), then monsoon (31.21\%) and summer (21.38\%). Separately herpes zoster (46.66\%) and Pityriasis rosea (56.66\%) occurred more in spring season. But genital herpes occurred more in summer season (32\%). So of all these diseases were more spread in spring season. In the present study, diabetic level is uncontrolled (46.24\%) and controlled (33.52\%). In case of herpes zoster the glycemic level was high (46.66\%) occurred uncontrolled patients.

Conclusion: Although viral diseases are self-limiting, due to immune compromised condition among diabetic subjects are often complicated with viral skin infections.

Keywords: Skin Disease; Diabetes; Prevalence of Herpes Zoster; Molluscum contagiosum, Genital Herpes; Chicken Pox; Pityriasis Rosa 


\section{Clinical Dermatology Open Access Journal}

\section{Introduction}

Skin and venereal diseases (SDV) causes major part of the total spectrum of illness. Though they cause negligible mortality. Recurrence, excessive use of chemicals and cosmetics, environment pollution. Delayed marriage and use of multiple partners with unprotected sex are major leading factors for the initiation and transmission of the disease [1]. Incidence of skin and venereal diseases are well established in western countries. In Bangladesh there is no surveillance system, so national data to determine the prevalence of STD's (Skin transmitted disease) and skin disease. However, small-scale studies have been carried out till date. Large community studies in the UK and USA have revealed that between $20 \%-30 \%$ of the population has a skin disease requiring attention, but only 1-5 of them will seek medical help. In spite of these some $10 \%$ of those who go to their family doctors do so with skin problem but selfmedication is much common than treatment prescribed by doctors [2]. In the country skin disease pattern were studied in the outdoor patients of Bogra Medical College Hospital [1], Dhaka [2], Khulna [3], Mymensingh [4] and Comilla [5]. The skin disease patterns were also studied in district hospital [6], and a textile mill [7], Ahmed, et al. [5], also reported the disease patterns of SDV patients, Herpes zoster, Pityriasis rosea, and genital herpes. Molluscum contagiosum, HPV, wart and chicken pox were important viral skin diseases described by several authors [1-8]. Herpes zoster is a common chronic inflammatory dermatosis affecting $1 \%$ to $2 \%$ of people in the US but frequently found in Korea Basit [10], conducted a study on herpes zoster in East Pakistan in 1966 and reported that herpes zoster is one of the commonest diseases in East Pakistan (now Bangladesh). It is constituted about $1.5 \%$ of the skin diseases in East Pakistan. The available statistics from other in south-east. Asia region suggest that the incidence of this infectious disease in Bangladesh is quite high due to poverty, illiteracy, increase growth rate, ignorance, urbanization, industrialization and socio-cultural change. Clinically herpes zoster most frequently affects the skin of the neck, shoulder, face, eyes, chest and other parts of the body $[9,10]$. Chicken pox is a common illness among kids but rarely found in diabetic patients. An itchy rash that look like blisters can appear all over the body and be accompanied by flu-like symptoms. Chicken pox is causes by the varicella zoster virus (YZY) [11]. Genital herpes is treatable but at present, incurable sexually transmitted infection caused by herpes simplex virus type-2 (HSV-2), usually acquired through genital-genital contact but also herpes simplex virus type-1 (HSV-1), usually through oral-genital contact. Although genital herpes is not a reported STD in CANADA, international data and clinical reports suggest that it is common. Factors associated with HSV-2 seroprevalence include age, lifetime number of sexually partners and being a female in a sexual relationship with an infected male. Risk of transmission is associated with lack of condom use and with frequency of asymptomatic viral shedding and symptomatic recurrences. This paper reviews current medical and epidemiological concepts related to genital herpes and purpose strategies for the control of genital herpes in Canada. These strategies include sero surveillance studies, public education, cost/ benefit analysis of suppressive therapy, development of less expensive and easier to perform screening tests and planning for the eventual deployment of a vaccine [11]. Molluscum contagiosum virus (MCV) lesions from Spanish human immunodeficiency virus (HIV) negative patients were clinically examined and analyzed for virus detection and typing. In a study of 147 patients, 97 (66\%) were children under 10 years of whom $49 \%$ had atopic dermatitis. MCV lesions were morphologically indistinguishable among the different age groups but atopic patients presented larger lesions compared with patients without the disorder. In adults, lesions were observed mainly on the genitals [5,7]. Sexually transmitted diseases are wide spread throughout the world due to easy availability of sexually partners. Industrialization peoples with workers living away from families, travelers seeking pleasure and amusement while move from country to country, prostitution and others social factors which help spread of disease are poverty, affluence wide scale unemployment, broken home, sexual disharmony, easy money, increased leisure and ignorance $[10,11]$.

\section{Methodology}

This present cross-sectional study was carried out in the department of Skin and VD, BIRDEM General Hospital, Dhaka, Bangladesh during the period of January, 2010 to December. 2010. This present study included a total number of 173 Diabetic subjects with viral skin diseases. Sample was purposively selected but sample size was not statistically calculated. After approval of protocol from Ethical review board, informed written consent was taken from all the subjects, followed by conduction of the study. Diseases were diagnosed on basis of clinical features by researcher and subsequently confirmed by two consultant Dermatologists, Data regarding age, gender, socio-economic status, season of occurrence, site of occurrence within body were recorded. Data was presented by table and was described accordingly.

\section{Results}

It was observed that the major proportion of the patients (43.35\%) were in the age group between 25 -34 years and the group $65+(0.8 \%)$. In case of herpes zoster, the major portion of disease $(34.67 \%)$ was between the group $45-54$ years. Another pityriasis rosea, the highest prevalence (33.33\%) was between age group 34-44 years. The genital herpes, the 


\section{Clinical Dermatology Open Access Journal}

major portion was (43.47\%) between age group 25-34 years and in case of Molluscum contagiosum and chicken pox the majority of patients $(60 \%$ and $40 \%)$ was between the age group 15-24 years (Table 1).

\begin{tabular}{|c|c|c|c|c|c|c|c|c|c|c|c|c|c|c|}
\hline Age Group & \multicolumn{2}{|c|}{$\mathbf{1 5 - 2 4}$} & \multicolumn{2}{|c|}{$\mathbf{2 5 - 3 4}$} & \multicolumn{2}{|c|}{$\mathbf{3 5 - 4 4}$} & \multicolumn{2}{|c|}{$\mathbf{4 5 - 5 4}$} & \multicolumn{2}{|c|}{$\mathbf{5 5 - 6 4}$} & \multicolumn{2}{|c|}{$\mathbf{6 5 +}$} & \multicolumn{2}{c|}{ Total } \\
\hline Disease & $\mathbf{n}$ & $\mathbf{9}$ & $\mathbf{n}$ & $\mathbf{\%}$ & $\mathbf{n}$ & $\mathbf{\%}$ & $\mathbf{n}$ & $\mathbf{\%}$ & $\mathbf{n}$ & $\mathbf{\%}$ & $\mathbf{n}$ & $\mathbf{\%}$ & $\mathbf{n}$ & $\mathbf{\%}$ \\
\hline Herpes zoster & 4 & 5.33 & 10 & 13.3 & 13 & 17.3 & 26 & 34.7 & 16 & 21.3 & 62 & 8 & 75 & 43.4 \\
\hline Pityriasis rosea & 5 & 16.7 & 7 & 23.3 & 10 & 33.3 & 3 & 10 & 3 & 10 & 2 & 6.7 & 30 & 17.4 \\
\hline $\begin{array}{c}\text { Molluscum } \\
\text { contagiosum }\end{array}$ & 15 & 60 & 8 & 32 & 5 & 20 & 2 & 8 & 0 & 0 & 0 & 0 & 25 & 14.5 \\
\hline Genital herpes & 6 & 26.1 & 10 & 43.5 & 4 & 17.4 & 2 & 8.69 & 1 & 4.35 & 0 & 0 & 23 & 13.3 \\
\hline Chicken pox & 8 & 4 & 5 & 25 & 3 & 15 & 2 & 10 & 2 & 10 & 0 & 0 & 20 & 11.6 \\
\hline Total & 38 & 22 & 40 & 23.7 & 35 & 20.2 & 35 & 20.2 & 22 & 12.7 & 8 & 4.6 & 173 & 100 \\
\hline
\end{tabular}

Table 1: Distribution of respondents by age and diseases.

From the present investigation it was seen that the majority $(64.16 \%)$ of the patients was male. The remaining (35.84\%) suffer more than female (33.33\%) in case of herpes zoster and all the disease such as pityriasis rosea, Molluscum contagiosum, genital herpes and chicken pox also male suffer more than female (Table 2).

\begin{tabular}{|c|c|c|c|c|c|c|}
\hline Diseases & Male & $\mathbf{\%}$ & Female & \% & Total & \% \\
\hline Herpes zoster & 50 & 66.67 & 25 & 33.33 & 75 & 43.35 \\
\hline Pityriasis rosea & 18 & 60 & 12 & 40 & 30 & 17.35 \\
\hline Molluscum contagisoum & 13 & 52 & 12 & 48 & 25 & 14.45 \\
\hline Genital herpes & 15 & 65.22 & 8 & 34.78 & 23 & 13.29 \\
\hline Chicken pox & 15 & 75 & 5 & 25 & 20 & 11.56 \\
\hline Total & 111 & & 62 & & & \\
\hline$\%$ & 64.16 & & 35.84 & & & \\
\hline
\end{tabular}

Table 2: Distribution of respondents by sex and diseases.

Out of 173 patients, $55.49 \%$ lower, $25.43 \%$ middle, $12.14 \%$ upper middle and $6.94 \%$ were belong to higher socioeconomic status (SES). Regarding socio-economic status it was observed that majority of the respondents (61.33\%) and
(60.87\%) were from lower status group having herpes zoster and genital herpes. In case of pityriasis rosea and Molluscum contagiosum were more prevalent in lower socio-economic status (50\% and $52 \%)$ (Table 3$)$.

\begin{tabular}{|c|c|c|c|c|c|c|c|c|c|c|}
\hline \multirow{2}{*}{ Disease } & \multicolumn{8}{|c|}{ Socio-economic status } & \multicolumn{2}{|l|}{ Total } \\
\hline & Lower & $\%$ & Middle & $\%$ & Upper middle & $\%$ & Higher class & $\%$ & Frequency & $\%$ \\
\hline Herpes & 46 & 61 & 15 & 20 & 10 & 13 & 4 & 5 & 75 & 43 \\
\hline zoster & & 3 & & & & 3 & & 3 & & 5 \\
\hline Pityriasis & 15 & 50 & 10 & 33 & 3 & 10 & 2 & 7 & 30 & 17 \\
\hline rosea & & & & 3 & & & & 7 & & 5 \\
\hline Molluscum & 13 & 52 & 8 & 32 & 2 & 8 & 2 & 8 & 25 & 14 \\
\hline contagisum & & & & & & & & & & 5 \\
\hline Genital & 14 & 61 & 6 & 26 & 2 & 8.7 & 1 & 4 & 23 & 13 \\
\hline herpes & & 7 & & 8 & & & & 5 & & 9 \\
\hline Chicken & 8 & 40 & 5 & 25 & 4 & 20 & 3 & 15 & 20 & 12 \\
\hline pox & & & & & & & & & & 6 \\
\hline Total & 96 & & 44 & & 21 & & 12 & & 173 & 100 \\
\hline$\%$ & 55.49 & & 25.43 & & 12.14 & 6.9 & & & & \\
\hline
\end{tabular}

Table 3: Distribution of the respondents by socio-economic status and diseases. 


\section{Clinical Dermatology Open Access Journal}

It was observed that the highest percentage of the respondents acquired the disease from the slum areas $(26.01 \%)$ and then infected lilen $(20.23 \%)$ and $14.45 \%$ and $13.29 \%$ patients were suffer from camps and jail. Also $8.67 \%$ and $5.78 \%$ patients were suffer from school source and playing partners and $11.56 \%$ were suffer husband and wife source (Table 4).

\begin{tabular}{|c|c|c|c|c|c|c|}
\hline Source & Male & $\mathbf{0}$ & Female & $\mathbf{\%}$ & Total & \% \\
\hline School & 10 & 66.67 & 5 & 33.33 & 10 & 8.78 \\
\hline Jail & 15 & 65.22 & 8 & 34.78 & 23 & 13.29 \\
\hline Slum Areas & 28 & 62.22 & 17 & 37.78 & 45 & 26.01 \\
\hline Lien/Towel & 23 & 65.71 & 12 & 34.28 & 35 & 20.23 \\
\hline Husband/Wife & 13 & 65 & 7 & 35 & 20 & 11.56 \\
\hline Playing Partners & 5 & 50 & 5 & 50 & 15 & 5.78 \\
\hline Total & 111 & 64.16 & 62 & 35.84 & 173 & 100 \\
\hline
\end{tabular}

Table 4: Distribution of respondents by sex and source of disease.

It was observed that most skin diseases occur in chest $(27.74 \%)$ and limbs (16.18\%). Majority of the respondents suffered from herpes zoster $(43.55 \%)$ of them $33.33 \%$ occur on chest. Next the second disease pityriasis rosea $(17.34 \%)$ of them $36.66 \%$ also occur on chest. But genital herpes occurred on groin (56.52\%) (Table 5).

\begin{tabular}{|c|c|c|c|c|c|c|c|c|c|c|c|c|c|c|}
\hline Disease & Frequency & $\mathbf{\%}$ & Face & \% & Chest & \% & Hands & \% & Limb & \% & Groin & \% & Backsides & \% \\
\hline $\begin{array}{c}\text { Herpes } \\
\text { Zoster }\end{array}$ & 75 & 45.6 & 10 & 13.3 & 25 & 33.3 & 10 & 13.3 & 13 & 17.3 & 2 & 2.6 & 15 & 20 \\
\hline $\begin{array}{c}\text { Pityriasis } \\
\text { rosea }\end{array}$ & 30 & 17.3 & 3 & 10 & 11 & 36.3 & 6 & 20 & 4 & 13.3 & 0 & 0 & 6 & 20 \\
\hline $\begin{array}{c}\text { Molluscum } \\
\text { contagiosum }\end{array}$ & 25 & 14.5 & 8 & 32 & 4 & 16 & 2 & 8 & 4 & 16 & 6 & 24 & 1 & 4 \\
\hline $\begin{array}{c}\text { Genital } \\
\text { Herpes }\end{array}$ & 23 & 13.3 & 0 & 0 & 1 & 4.3 & 2 & 8.6 & 5 & 21.7 & 13 & 56.5 & 2 & 8.7 \\
\hline Chicken Pox & 20 & 11.6 & 4 & 20 & 7 & 35 & 3 & 15 & 2 & 10 & 1 & 5 & 3 & 15 \\
\hline Total & 173 & 100 & 25 & & 48 & & 23 & & 28 & & 22 & & 27 & 15.6 \\
\hline$\%$ & & & 14.45 & & 27.7 & & 13.29 & & 16.2 & & 12.7 & & 15 \\
\hline
\end{tabular}

Table 5: Site of distribution of lesion.

Regarding seasonal variation highest percentage of diseases occur in spring season (47.30\%), then monsoon (31.21\%) and summer (21.38\%). Separately herpes zoster (46.66\%) and Pityriasis rosea (56.66\%) occurred more in spring season. But genital herpes occurred more in summer season (32\%). So of all these diseases were more spread in spring season (Table 6).

\begin{tabular}{|c|c|c|c|c|c|c|c|c|}
\hline Disease & Frequency & $\mathbf{\%}$ & Spring & $\mathbf{\%}$ & Monsoon & $\mathbf{\%}$ & Summer & $\mathbf{\%}$ \\
\hline Herpes Zoster & 75 & 43.55 & 35 & 46.7 & 25 & 33.3 & 15 & 20 \\
\hline Pityriasis rosea & 30 & 17.34 & 17 & 56.7 & 9 & 30 & 4 & 13.3 \\
\hline Molluscum contagiosum & 25 & 14.45 & 12 & 48 & 8 & 32 & 5 & 20 \\
\hline Genital Herpes & 23 & 13.29 & 8 & 34.8 & 5 & 21.7 & 10 & 43.5 \\
\hline Chicken Pox & 20 & 11.56 & 10 & 50 & 7 & 35 & 3 & 15 \\
\hline Total & 173 & 100 & 82 & & 54 & & 37 & \\
\hline$\%$ & & & 47.39 & & 31.21 & & 21.38 & \\
\hline
\end{tabular}

Table 6: Distribution of respondents with seasonal variation. 


\section{Clinical Dermatology Open Access Journal}

In the present study out of 173 patients with diabetes, diabetic level is un-controlled (46.24\%) and controlled
(33.52\%). In case of herpes zoster the glycemic level was high (46.66\%) occurred uncontrolled patients (Table 7).

\begin{tabular}{|c|c|c|c|c|c|c|c|c|}
\hline \multirow{2}{*}{ Disease } & \multicolumn{9}{|c|}{ Glycemic Level } & \multicolumn{3}{c|}{ Total } \\
\cline { 2 - 10 } & $\begin{array}{c}\text { Strictly } \\
\text { Controlled }\end{array}$ & $\mathbf{\%}$ & Controlled & $\mathbf{\%}$ & Un-Controlled & $\mathbf{\%}$ & Frequency & \% \\
\hline Herpes Zoster & 15 & 20 & 25 & 33.3 & 35 & 46.7 & 75 & 43.6 \\
\hline Pityriasis rosea & 5 & 16.66 & 10 & 33.3 & 15 & 50 & 30 & 17.3 \\
\hline $\begin{array}{c}\text { Molluscum } \\
\text { contagiosum }\end{array}$ & 6 & 24 & 7 & 28 & 12 & 48 & 25 & 14.5 \\
\hline Genital Herpes & 6 & 26.08 & 7 & 30.4 & 10 & 43.5 & 23 & 13.3 \\
\hline Chicken Pox & 3 & 15 & 9 & 45 & 8 & 40 & 20 & 11.6 \\
\hline Total & 35 & 20.23 & 58 & 33.5 & 80 & 46.2 & 173 & 100 \\
\hline
\end{tabular}

Table 7: Distribution of respondents by diabetic level (glycemic level).

\section{Discussion}

Skin and venereal disease is one of the major public health problems of the mankind. These are found in more or less all age sexes and classes of the society and create community health problems in developing countries. People within sanitary, overcrowding, poor housing, lack of knowledge regarding disease transmission are suffered more with skin disease. The present study was carried out with the objective to find out prevalence of different viral disease among diabetic subjects and to provide a descriptive profile of prevalence of herpes zoster, Pityriasis rosea, Molluscum contagiosum, genital herpes and chicken pox among the diabetic patients. In presentstudy, regarding viral skin disease among diabetes, highest proportions were herpes zoster $43.35 \%$ followed by Pityriasis rosea $(17.34 \%)$ then chicken pox were $(11.56 \%)$. In case of sexually transmitted diseases, Molluscum contagiosum obtained highest proportion $14.45 \%$ least percentage of genital herpes (13.29\%). Herpes zoster, Pityriasis rosea, genital herpes, Molluscum contagiosum, HPV, wart and chicken pox were important viral skin diseases described by several authors [1-8]. This study also strongly supported by a study conducted by Ahad, et al. [3], in private chamber of skin and VD, showed that out of total cases only $13.7 \%$ were suffered from STDs. It was observed that the major proportion of the patients $(43.35 \%)$ were in the age group between $25-34$ years and the group $65+(0.8 \%)$. In case of herpes zoster, the major portion of disease (34.67\%) was between the group 45-54 years. Another pityriasis rosea, the highest prevalence (33.33\%) was between age group 34-44 years. The genital herpes, the major portion was (43.47\%) between age group 25-34 years and in case of Molluscum contagiosum and chicken pox the majority of patients $(60 \%$ and $40 \%)$ was between the age group 15-24 years. From the present investigation it was seen that the majority (64.16\%) of the patients was male. The remaining
(35.84\%) were female. Rahman, et al. [1], and Ahmed, et al. [5], observed the comparable result. They observed that majority of the respondents were male with majority of the respondents were aged around 30 years of age. Out of 173 patients, $55.49 \%$ lower, $25.43 \%$ middle, $12.14 \%$ upper middle and $6.94 \%$ were belonging to higher socio-economic status. Most of the patients were coming from urban area $(46.82 \%)$ then semi-urban areas $(31.39 \%)$ in which zoster (46.67\%) were coming from urban area. But Ahmed [5], reported that $45.20 \%$ herpes zoster patients were coming from urban area. In this study lower socio-economic group of patients occupied $61.33 \%$ for herpes zoster, $50 \%$ for pityriasis rosea and $40 \%$ for chicken pox but Ahad, et al. [3], in a study reported that only $9.5 \%$ of patients were from poor class. It was probably the fact that rich people attend the private chamber that the poor one. They also showed that STDS were of higher prevalence. But in this series it occupies the second position due to area and socio-variation. Majority of the respondents acquired the disease from the slum areas (26.01\%) and then infected lilen $(20.23 \%)$ and $14.45 \%$ and $13.29 \%$ patients were suffer from camps and jail. Slum area living people and infected linen were the principle source of infection as higher proportion of the respondents were poor socio-economic class which may be the major contributing factor for illuminating of personal hygiene. Rouf, et al who showed that slum areas living persons took major part $(26.01 \%)$ regarding disease suffering. The highest proportion of recurrence was in housewives followed by rickshaw-puller. Most skin diseases occur in chest (27.74\%) and limbs $(16.18 \%)$. But genital herpes occurred on groin (56.52\%). Regarding seasonal variation highest percentage of diseases occur in spring season (47.30\%), then monsoon (31.21\%) and summer (21.38\%). Separately herpes zoster (46.66\%) and Pityriasis rosea (56.66\%) occurred more 'in spring season. But genital herpes occurred more in summer season $(32 \%)$. So of all these diseases were more spread in 
spring season. In previous studies $[1,4,5,7]$, it was seen that viral skin disease occurred most commonly from the period of February to July. The study was compatible to the study of the number of skin patients and patients of herpes zoster, Pityriasis rosea, Molluscum contagiosum, genital herpes and chicken pox cases attending the department of dermatology, Dhaka Medical College Hospital from August 1959 to October 1965 [9]. The study was carried out in August of 1959, 1960, 1961, 1962, 1963, and 1964 and in October in 1965. The percentage of herpes zoster, Pityriasis rosea and chicken pox in August 1959 were 0.78, in August, 1960 was 1.53\%, in August, 1961 was 1.33\%, in August, 1962 was $0.66 \%$ in august, 1963 was $1.15 \%$ and in august, 1964 was $1.33 \%$. The percentage of herpes zoster, Pityriasis rosea and chicken pox in October, 1965 was $1.58 \%$.

\section{Conclusion}

Although sample size was 173 , it was not statistically calculated. Results were discussed on basis of data of 10-30 years old statistics as recent data regarding viral skin disease was not available. Though viral diseases are self-limiting, due to immune compromised condition in diabetes, diabetic subjects are often complicated with viral skin infections. However, this present study will provide necessary information to the Dermatologist to assess viral skin diseases among diabetic subjects and further follow-up study with a large sample size involving multiple centers is recommended.

\section{References}

1. Rahman S, Alani J, Awal A, Islam R, Nurul AKM (1988) Pattern of skin diseases in skin and VD-OPD in Bogra Medical College. J of Bogra Med Coll 4(5): 9-11.

2. Rouf MA, Banu RA, Majumdar A (1998) A study on pattern of skin and venereal disease in Rangpur Medical College Hospital. North Medical 7(1): 5-8.

3. Ahad SMMA, All A, Maidul AZM (1994) Disease pattern of patients attended in private chambers of Dermatologist and venerologist and sex related disorders. Bangladesh J DermatoI Venerol Leprol II 9(2): 34-36.

4. Farah M (1994) Types of dermatophytes found in the Department of Skin and Venereal Disease in MMCH. Mymensingh Med J 8(1): 42-44.

5. Ahmed AM, Haque M, Sadir AM (2003) Pattern of skin diseases in the in patients department of Comilla Medical College Hospital. J Comilia Med Coll 5(1): 6-12.

6. Hossain MM (1993) Pattern of skin and sexually transmitted disease in districts hospitals. Bangladesh J Dermatol Venerol Leprol 10(2): 7-9.

7. Shamsuddin MA (1990) Study on pattern of skin and venereal diseases in a Textile Mill, Bangladesh. J Dermatol Venerol Leprol 8(1): 1-4.

8. Begum R (1999) Socio-Demographic Characterization of patient attending in skin and VD of outpatient department of Khulna Medical College Hospital (Dissertation). NIPSOM, pp: 1-98.

9. Bhuyia AL (1997) A study of skin disease pattern at the outpatient department of Dhaka Medical College Hospital. J Dhaka Med Coll 1(2): 18-23.

10. Basit A (1996) A study of viral disease in East Pakistan, Pakistan. J Med Rsc 1: 294-304.

11. WHO (1993) Population Report, Controling STD, Series L, Number I, Issue in World Health, WHO Tech Rep Ser 749: 619-624. 